\title{
HANDBOOK OF NEUROCHEMISTRY
}

\author{
VOLUME VI
}

ALTERATIONS OF CHEMICAL EQUILIBRIUM

IN THE NERVOUS SYSTEM 


\section{HANDBOOK OF NEUROCHEMISTRY}

\section{Edited by Abel Lajtha}

Volume I Chemical Architecture of the Nervous System

Volume II Structural Neurochemistry

Volume III Metabolic Reactions in the Nervous System

Volume IV Control Mechanisms in the Nervous System

Volume V Metabolic Turnover in the Nervous System

Volume VI Alterations of Chemical Equilibrium in the Nervous System

Volume VII Pathological Chemistry of the Nervous System 


\title{
HANDBOOK OF NEUROCHEMISTRY \\ Edited by Abel Lajtha
}

New York State Research Institute

for Neurochemistry and Drug Addiction Ward's Island

New York, New York

\author{
VOLUME VI \\ ALTERATIONS OF \\ CHEMICAL EQUILIBRIUM \\ IN THE NERVOUS SYSTEM
}

P PLENUM PRESS • NEW YORK-LONDON • 1971 


\section{Library of Congress Catalog Card Number 68-28097}

\section{SBN 306-37706-3}

ISBN 978-1-4615-7177-3

ISBN 978-1-4615-7175-9 (eBook)

DOI 10.1007/978-1-4615-7175-9

(C) 1971 Plenum Press, New York

Softcover reprint of the hardcover 1st edition 1971

A Division of Plenum Publishing Corporation 227 West 17th Street, New York, New York 10011

United Kingdom edition published by Plenum Press, London

A Division of Plenum Publishing Company, Ltd.

Davis House (4th Floor), 8 Scrubs Lane, Harlesden, NW10 6SE, England

\section{All rights reserved}

No part of this publication may be reproduced in any form without written permission from the publisher 


\section{Contributors to this volume:}

Bernard W. Agranoff

V. A. Benignus

Edward L. Bennett

R. G. Benton

Doris H. Clouet

Jill E. Cremer

Wolf-Dietrich Dettbarn

John Dobbing

Enrique Egaña

Elliot S. Gershon
University of Michigan, Ann Arbor, Michigan (page 203)

Department of Neurology and Psychiatry, The University of Texas Medical Branch, Galveston, Texas (page 1)

Laboratory of Chemical Biodynamics, Lawrence Radiation Laboratory, University of California, Berkeley, California (page 173)

Department of Neurology and Psychiatry, The University of Texas Medical Branch, Galveston, Texas (page 1)

New York State Narcotic Addiction Control and Commission Testing and Research Center, Brooklyn, New York (page 479)

Biochemical Mechanisms Section, Toxicology Research Unit, Medical Research Council, Woodmansterne Road, Surrey, England (page 311)

Department of Pharmacology, Vanderbilt University School of Medicine, Nashville, Tennessee (page 423)

Department of Child Health, Clinical Sciences Building, University of Manchester, Manchester, England (page 255)

Laboratory of Neurochemistry-Institute of Experimental Medicine, School of Medicine, University of Chile, P.O.B. 3170, Santiago, Chile (page 525)

Sabit Gabay Biochemical Research Laboratory, Veterans Administration Hospital, Brockton, Massachusetts (page 325)

Neuropsychopharmacology Laboratory, Massachusetts Mental Health Center, Department of Psychiatry, Harvard Medical School, Boston, Massachusetts (page 357) 
Holger Hydén Institute of Neurobiology, Faculty of Medicine, University of Göteborg, Göteborg, Sweden (page 221)

Paul W. Lange Institute of Neurobiology, Faculty of Medicine, University of Göteborg, Göteborg, Sweden (page 221)

G. M. Lehrer

Department of Neurology, The Division of Neurochemistry, The Mount Sinai School of Medicine of the City University of New York, New York, New York (page 267)

Richard A. Lovell Department of Psychiatry, University of Chicago, Chicago, Illinois (page 63)

H. S. Maker Department of Neurology, The Division of Neurochemistry, The Mount Sinai Schoolof Medicine of the City University of New York, New York, New York (page 267)

L. J. Mullins Department of Biophysics, University of Maryland School of Medicine, Baltimore, Maryland (page 395)

M. K. O'Heeron, Jr. Department of Pediatrics, The University of Texas Medical Branch, Galveston, Texas (page 1)

Giuseppe Porcellati

Department of Biological Chemistry, University of Pavia, Pavia, Italy (page 457)

D. A. Rappoport

Department of Pediatrics, The University of Texas Medical Branch, Galveston, Texas (page 1)

Mark R. Rosenzweig

Department of Psychology, University of California, Berkeley, California (page 173)

Joseph J. Schildkraut Neuropsychopharmacology Laboratory, Massachusetts Mental Health Center, Department of Psychiatry, Harvard Medical School, Boston, Massachusetts (page 357) 
Mogens Schou The Psychopharmacology Research Unit, Aarhus University Psychiatric Institute, Risskov, Denmark (page 387)

P. A. Shore Department of Pharmacology, University of Texas Southwestern Medical School, Dallas, Texas (page 349)

U. B. Singh Department of Biochemistry, All-India Institute of Medical Sciences, New Delhi, India (page 29)

Stephen I. Szara Section on Psychopharmacology, Division of Special Mental Health Research, National Institute of Mental Health, St. Elizabeths Hospital, Washington, D.C. (page 441)

G. P. Talwar Department of Biochemistry, All-India Institute of Medical Sciences, New Delhi, India (page 29)

N. M. Trieff Department of Pharmacology and Toxicology, The University of Texas Medical Branch, Galveston, Texas (page 1)

Georges Ungar Baylor College of Medicine, Houston, Texas (page 241)

Henrik Wallgren Research Laboratories of the State Alcohol Monopoly (Alko), Helsinki, Finland (page 509)

Arthur Yuwiler Neurobiochemistry Laboratory, Veterans Administration Center, and Department of Psychiatry, University of California Center for the Health Sciences, Los Angeles, California (page 103) 


\section{PREFACE}

It has been recognized for more than a thousand years that the function of the brain, like the function of the other organs of the body, is determined by its physical, chemical, and biological properties. Evidence that even its highest functions could be explained by these properties was gathered only in recent years, however; these findings, which clearly have to be confirmed by a great deal of further experimental evidence, indicate that most, if not all, of the functions of the brain are based on its biochemical and biophysical mechanisms. This at first hearing may sound rather simple, but the ability to understand learning, emotion, perhaps even creativity, on biological terms may well be the most important scientific discovery of all time. Few pieces of knowledge can influence our future health and well-being to the degree that understanding of mental mechanisms will.

It has been clearly shown in many ways in the previous volumes of this Handbook that from the biochemical or neurochemical point of view the brain is one of the most active organs. The brain seems stable and in some respects permanent; this is evidence not of inactivity but of carefully controlled homeostasis, of dynamic rather than static equilibrium, with most components undergoing metabolic alterations. What this dynamic equilibrium entails is that brain possesses plasticity; its very active biological processes are likely to impart some stability, the possibility of repairing damage, certainly the possibility of adapting to varying situations and conditions. These dynamic processes, however, also give this organ a vulnerability not always fully realized. The mere existence of dynamic processes brings with it the possibility of influencing such processes. The present volume emphasizes the vulnerability of the nervous system, and makes one wish that in the present time, when so many try to experiment with substances or conditions that influence the brain or mental states, this vulnerability of the nervous system would be more widely appreciated and respected. This heuristic aim, however, is beyond the scope of the present volume, which is designed more for researchers engaged in prying the secrets of biological mechanisms from the nervous system. These chapters clearly demonstrate that cerebral chemical processes can be influenced in a number of ways, and can undergo changes that in turn will influence the functions of the nervous system. Surely this is one of the most exciting fields of neurochemistry, and one that needs many dedicated investigators. The number of problems waiting 
to be investigated is great; these chapters not only show which ones have been investigated, but also indicate a great many unmapped areas that need to be explored.

New York, New York

December 1970.

Abel Lajtha 


\section{CONTENTS}

\section{Chapter 1}

Chemosensory Stimulation $\ldots \ldots \ldots \ldots \ldots \ldots \ldots \ldots \ldots \ldots . \ldots \ldots$ by D. A. Rappoport, N. M. Trieff, M. K. O'Heeron, Jr.,

V. A. Benignus, and R. G. Benton

I. Introduction $\ldots \ldots \ldots \ldots \ldots \ldots \ldots \ldots \ldots \ldots \ldots, 2$

II. Olfaction $\ldots \ldots \ldots \ldots \ldots \ldots \ldots \ldots \ldots \ldots \ldots \ldots \ldots, 5$

III. Gustation $\ldots \ldots \ldots \ldots \ldots \ldots \ldots \ldots \ldots \ldots \ldots \ldots . \quad 11$

IV. Impulse Propagation and Membrane Changes ....... 15

V. Sensory Information Accrual in the Brain $\ldots \ldots \ldots \ldots .20$

VI. References.......................... 23

\section{Chapter 2}

Excitation.

by G. P. Talwar and U. B. Singh

I. Introduction ....................... 29

II. Dynamics of Ions and Excitability in the Nerve Tissue . 29

A. Resting Potentials ................... 29

B. Excitation: Flux of Sodium ................ 33

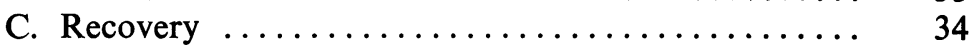

III. Excitable Membranes $\ldots \ldots \ldots \ldots \ldots \ldots \ldots \ldots . .6 \ldots$

A. Changing Notions on Structure ............ 35

B. Conformational Alterations............... 37

C. Some Cell Products Causing Excitation ....... 37

IV. Ontogenesis of Electrical Activity $\ldots \ldots \ldots \ldots \ldots \ldots .38$

A. Developing Brains of Different Species ........ 38

B. Possible Factors Related to Ontogenesis of Electrical Activity ........................ 39

V. General Effects of Excitatory Activity on Metabolism of the Nervous Tissue ..................... 41

A. Energy Metabolism ...................... 41

B. Phospholipid Metabolism $\ldots \ldots \ldots \ldots \ldots \ldots .42$

C. RNA Metabolism $\ldots \ldots \ldots \ldots \ldots \ldots \ldots \ldots .43$

D. Protein Metabolism $\ldots \ldots \ldots \ldots \ldots \ldots \ldots, 45$ 
VI. Effect of Ions on Metabolic Reactions ........... 49

A. Enzymes Strongly Activated by Potassium ....... 50

B. Ion-Induced Stimulation of Respiration in Neural Tissue ......................... 50

C. Effect of Ions on Metabolism of Phospholipids .... 51

D. Effect of Ions on Transport of Amino Acids .... 51

E. Effect of Ions on RNA and Protein Metabolism ... 52

F. Effect of Electrolytes on Memory and Learning .... 52

VII. References........................... 53

\section{Chapter 3}

Some Neurochemical Aspects of Convulsions $\ldots \ldots \ldots \ldots \ldots \ldots, 63$ by Richard A. Lovell

I. Introduction ...................... 63

A. Convulsions from the Point of View of Neurochemistry $\ldots \ldots \ldots \ldots \ldots \ldots \ldots \ldots \ldots .6 .63$

B. Scope and Purpose of this Chapter ........... 63

C. Review of Reviews .................... 64

II. Biochemical Studies of Convulsions ............. 64

III. The Role of Certain Brain Amino Acids and Amines in Convulsive Mechanisms .................. 66

A. Relationship of Glutamic Acid-GABA System to Convulsions ....................... 67

B. Amines and Convulsions $\ldots \ldots \ldots \ldots \ldots \ldots \ldots$

C. Binding Studies ........................ 82

IV. Concluding Remarks $\ldots \ldots \ldots \ldots \ldots \ldots \ldots \ldots, \quad 85$

V. References.......................... 88

\section{Chapter 4}

Stress....................................... 103

by Arthur Yuwiler

I. Introduction $\ldots \ldots \ldots \ldots \ldots \ldots \ldots \ldots \ldots \ldots \ldots \ldots$

II. Physiology $\ldots \ldots \ldots \ldots \ldots \ldots \ldots \ldots \ldots \ldots \ldots \ldots, 103$

A. Hypothalamic-Pituitary-Adrenal Interrelations .... 104

B. Adrenocortical Hormones ................. 107

C. Adrenal Catecholamines $\ldots \ldots \ldots \ldots \ldots \ldots \ldots .118$

III. Stressors . . . . . . . . . . . . . . . . . . . . . 122

A. Psychological Stressors $\ldots \ldots \ldots \ldots \ldots \ldots \ldots \ldots, 122$

B. Physiological Stressors $\ldots \ldots \ldots \ldots \ldots \ldots \ldots 134$

IV. Conclusion ........................... 143

V. References........................... 145 
Chapter 5

Chemical Alterations Produced in Brain by Environment and Training by Edward L. Bennett and Mark R. Rosenzweig

I. Introduction ........................ 173

II. Environmental Effects on Brain Chemistry .......... 174

A. Biogenic Amines ........................ 174

B. Amino Acids . .................... 180

C. Nucleic Acids ......................... 181

D. Proteins and Enzymes $\ldots \ldots \ldots \ldots \ldots \ldots \ldots . . \ldots 182$

III. Effects of Training on Brain Chemistry ........... 184

A. Effects on Deoxynucleic Acid .............. 184

B. Effects on Ribonucleic Acid $\ldots \ldots \ldots \ldots \ldots \ldots .185$

C. Effects on Protein ....................... 190

D. Effects on Brain Mucoids $\ldots \ldots \ldots \ldots \ldots \ldots \ldots . \ldots 193$

IV. Discussion and Conclusions $\ldots \ldots \ldots \ldots \ldots \ldots \ldots . \ldots 194$

V. References............................. 196

\section{Chapter 6}

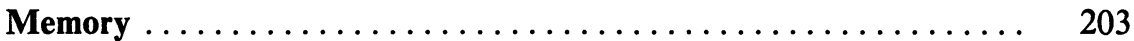

by Bernard W. Agranoff

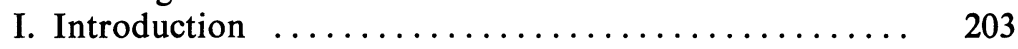

A. Definitions ........................ 203

B. The Brain and Evolution ............... 204

C. Morphological Approaches ............... 204

D. Electrophysiological Approaches ............. 205

II. Biochemical Studies ..................... 206

A. Concomitant Changes $\ldots \ldots \ldots \ldots \ldots \ldots \ldots 206$

B. Disruption of Memory Formation .......... 208

C. The Nature of Concomitant Biochemical Changes .. 214

D. Genetic Approaches ..................... 215

III. References......................... 215

\section{Chapter 7}

Do Specific Biochemical Correlates to Learning Processes Exist in Brain Cells?

by Holger Hydén and Paul W. Lange

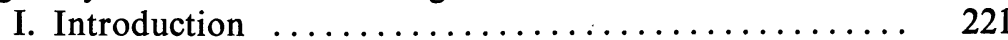

A. Neuronal and Glial Proteins .............. 221

B. An Immunological Study of Dieters' Nucleus ...... 222

II. Altered Protein Synthesis During Training-Handedness

Transfer............................... 
A. Incorporation of ${ }^{3} \mathrm{H}$-Leucine into the Acidic Protein Fractions 4 and $5 \ldots \ldots \ldots \ldots \ldots \ldots \ldots \ldots, 227$

B. Increased Syntheses of S100 Protein ......... 231

III. Sensory Conditioning Test in Rats ............ 235

A. Incorporation of ${ }^{3} \mathrm{H}$-Leucine into Neuronal Protein 235

IV. Discussion .......................... 236

V. References......................... 238

\section{Chapter 8}

Chemical Transfer of Information...................... 241 by Georges Ungar

I. Introduction ...................... 241

II. Transfer of Learned Behavior in Planarians ........ 242

III. Chemical Transfer in Vertebrates .............. 242

IV. Chemical Nature of the Transfer Factors .......... 246

V. Molecular Mechanisms of Information Processing .... 248

VI. References............................. 250

\section{Chapter 9}

Undernutrition and the Developing Brain .............. 255 by John Dobbing

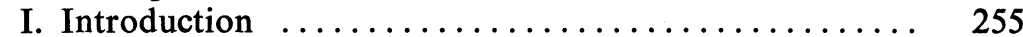

II. Historical Background .................... 256

III. The Vulnerable Period Hypothesis ............ 257

IV. Neurochemical Indices of Developing Structure...... 258

V. Interspecies Comparisons .................. 260

VI. Undernutrition and Developing Structure......... 261

VII. Underlying Mechanism of the Vulnerable Period ..... 262

VIII. Behavioral Effects ........................ 263

IX. References........................... 264

\section{Chapter 10}

Effect of Ischemia .............................. 267

by H. S. Maker and G. M. Lehrer

I. Introduction $\ldots \ldots \ldots \ldots \ldots \ldots \ldots \ldots \ldots \ldots, 267$

II. Methodology ........................ 267 
III. Vascular Factors ...................... 271

IV. Metabolic Changes in Whole Brain $\ldots \ldots \ldots \ldots \ldots .272$

A. Carbohydrate Metabolites ............... 273

B. Other Metabolic Changes During Ischemia ....... 283

V. Electrolyte and Functional Changes............. 285

VI. Late Chemical and Structural Changes During Ischemia 287

VII. Hypoglycemia and Hypoxia ............... 289

VIII. Seizure Studies and Ischemia ................ 290

IX. Response to Ischemia by Brain Cells of Various Types... 290

X. Regional Effects of Ischemia ................ 292

XI. The Problem of Selective Vulnerability ......... 295

XII. Age and Response to Ischemia .............. 296

XIII. Peripheral Nerve ......................... 298

XIV. Glial Tumors .......................... 299

XV. Summary............................ 300

XVI. References........................ 301

Chapter 11

Body Temperature and Drug Effects $\ldots \ldots \ldots \ldots \ldots \ldots \ldots \ldots, 311$

by Jill E. Cremer

I. Introduction $\ldots \ldots \ldots \ldots \ldots \ldots \ldots \ldots \ldots \ldots \ldots \ldots \ldots \ldots, 311$

II. Hypothermia $\ldots \ldots \ldots \ldots \ldots \ldots \ldots \ldots \ldots \ldots \ldots, 312$

A. Neurochemical Changes $\ldots \ldots \ldots \ldots \ldots \ldots \ldots, \quad 312$

B. Effect of Environmental Temperature $\ldots \ldots \ldots \ldots, 315$

III. Hyperthermia .......................... 317

A. Neurochemical Changes ............... 317

IV. Metabolism and Distribution of Drugs in Relation to the CNS ....................... 318

A. Body Temperature and Environmental Temperature 318

V. Concluding Remarks ................... 320

A. Possible Use of Drugs in Understanding Thermo-

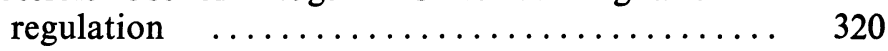

VI. References........................... 321

Chapter 12

Phenothiazines: Neurochemical Aspects of Their Mode of Action ... by Sabit Gabay

I. Introduction and Purpose $\ldots \ldots \ldots \ldots \ldots \ldots \ldots \ldots$

II. Effects of Phenothiazines on the Metabolic Processes in the Nervous System 
A. Effects on Cerebral Respiration and Glycolysis .... 326

B. Effects on Oxidative Phosphorylation and Related Processes .............................. 327

C. Recapitulative Discussion ............... 328

III. Phenothiazines and Alterations in Membrane Permeability

A. Effects on Cellular and Subcellular Membranes ... 329

B. Effects on Brain Amines .................. 331

IV. Phenothiazines and Brain Lipids $\ldots \ldots \ldots \ldots \ldots \ldots . \quad 332$

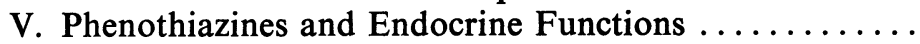

VI. Synopsis of Information on Past, Current, and Future Research

A. Collating Salient Points of Available Data ...... 335

B. Phenothiazines and FAD-Requiring Enzymes $\ldots . \quad 335$

C. Viewpoints Projected Toward Future Research .... 337

VII. References........................... 338

VIII. Appendix-Some Recent Review Articles of Special Interest

\section{Chapter 13}

Reserpine: A Survey of Its Pharmacology ............... 349 by P. A. Shore

I. Introduction $\ldots \ldots \ldots \ldots \ldots \ldots \ldots \ldots \ldots \ldots \ldots, \quad 349$

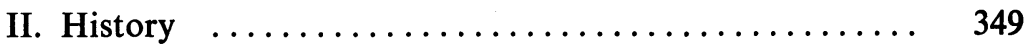

III. Pharmacology of Reserpine $\ldots \ldots \ldots \ldots \ldots \ldots \ldots \ldots, 350$

A. General Effects $\ldots \ldots \ldots \ldots \ldots \ldots \ldots \ldots \ldots, 350$

B. Absorption, Localization, and Disposition ....... 351

C. Actions on Monoamine Storage and Metabolism .. 351

IV. Conclusion ........................... 354

V. References............................ 355

\section{Chapter 14}

Antidepressants and Related Drugs................... 357

by Joseph J. Schildkraut and Elliot S. Gershon

I. Introduction ......................... 357

II. Characteristics of the Affective Disorders ......... 357

III. Effects of Antidepressant and Related Drugs on Clinical State and Behavior ...................... 358

IV. Chemical Effects of Drugs Used in the Treatment of the Affective Disorders .......................... 361

A. Tricyclic Antidepressant Drugs $\ldots \ldots \ldots \ldots \ldots \ldots . \ldots 363$

B. Monoamine Oxidase Inhibitors $\ldots \ldots \ldots \ldots \ldots .366$ 
C. Electroconvulsive Therapy $\ldots \ldots \ldots \ldots \ldots \ldots \ldots . \quad 367$

D. Amphetamine........................ 368

E. Cocaine ......................... 369

F. Reserpine and Reserpinelike Drugs $\ldots \ldots \ldots \ldots .370$

G. Lithium Salts $\ldots \ldots \ldots \ldots \ldots \ldots \ldots \ldots \ldots \ldots$

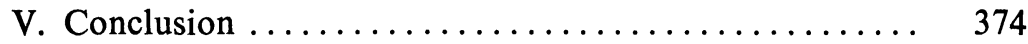

VI. References.......................... 375

\section{Chapter 15}

Lithium

I. Introduction-Therapeutic and Prophylactic Properties

II. Distribution in the Organism

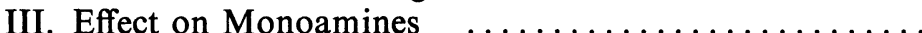

IV. Effect on Electrolytes ...................... 389

V. Effect on Intermediary Metabolism ............. 389

VI. Effect on Nervous Transmission ............... 390

VII. References................................. 391

\section{Chapter 16}

Anesthetics

by L. J. Mullins

I. Introduction

II. Solutions .............................. 396

A. Nonideal Solutions $\ldots \ldots \ldots \ldots \ldots \ldots \ldots \ldots . \ldots \ldots$

B. Ideal Solutions . . . . . . . . . . . . . . . . . . . . 397

C. Hydrate versus Lipid Solubility Correlations with Anesthetic Action ...................... 400

III. Processes Affected by Anesthetics.............. 401

A. Anesthesia in Nerve Fibers ................. 402

B. Anesthesia at Synapses .................. 404

C. Effects on the Central Nervous System ........ 405

D. Effects of Anesthetics on Unicellular Organisms ... 405

IV. Biochemical versus Biophysical Modes of Anesthetic Action ........................... 406

A. The Depression of $\mathrm{Na}$ Transport Activity by Anesthetics ....................... 406

B. Chemical Transformation of Anesthetic Agents ... 407

C. Interaction of Anesthetics with Proteins ......... 407

V. Mechanism of Anesthetic Action ................. 409

A. Enzyme Inhibition.................. 409

B. Interference with Neuronal Transmission ....... 410 
C. Interference with Ion Interchange in Axons ..... 411

D. Irreversible Actions of Anesthetics ........... 412

VI. The Design of Practical Anesthetics ............ 413

A. Molecular Size ..................... 413

B. The Distribution of Electron-Dense Substituents .. 417

C. Structural Requirements for Anesthetic Action .... 418

VII. Future Research ....................... 419

VIII. References............................... 423

\section{Chapter 17}

Local Anesthetics

by Wolf-Dietrich Dettbarn

I. Introduction

II. The Nature of the Nerve Impulse

III. The Effect of Local Anesthetics on Conduction.........

IV. Mechanism of Action

A. Structure-Activity Relationship

B. The Active Form of Local Anesthetics

C. Interaction with the ACh System

D. The Membrane

E. Mode of Local Anesthetic Action

F. Models

V. Conclusion

VI. References

\section{Chapter 18}

Hallucinogens

by Stephen I. Szara

I. Introduction: Scope and Extent

II. Metabolism of Hallucinogens Relevant to Mechanisms of Action

A. Lysergic Acid Diethylamide (LSD) and Related Indole Derivatives

B. Mescaline and the Hallucinogenic Phenylethylamine Derivatives.

III. Alteration of Neurochemical Parameters and Suggested Mechanisms of Action ...

A. Interrelationships with Serotonin

B. Interrelationships with Catecholamines

C. Interactions with Miscellaneous Neurochemical

Substances

IV. Summary

V. References 
Chapter 19

Demyelinating Cholinesterase Inhibitors: Lipid and Protein Metabolism $\ldots \ldots \ldots \ldots \ldots \ldots \ldots \ldots \ldots \ldots \ldots \ldots \ldots . \ldots \ldots \ldots$ by Giuseppe Porcellati

I. Introduction $\ldots \ldots \ldots \ldots \ldots \ldots \ldots \ldots \ldots \ldots \ldots \ldots$

A. The Demyelinating Organophosphorus Compounds. 457

B. Toxicology .......................... 458

C. Animal Species Susceptibility .............. 459

II. A Brief Description of the Neuropathological Studies .. 459

III. Lipid Metabolism ...................... 461

A. Lipid Class Concentration and Constitution ..... 461

B. Lipid Synthesis $\ldots \ldots \ldots \ldots \ldots \ldots \ldots \ldots \ldots . \ldots . \ldots . \ldots 1$

C. Lipid Degradation........................ 465

D. Fatty Acid Metabolism $\ldots \ldots \ldots \ldots \ldots \ldots \ldots . . \ldots 466$

E. Discussion ....................... 466

IV. Protein Metabolism...................... 468

A. The Concentration of Protein, Amino Acids, and Related Compounds .................. 468

B. Protein Synthesis ....................... 469

C. Protein Degradation $\ldots \ldots \ldots \ldots \ldots \ldots \ldots \ldots .469$

D. Discussion ....................... 470

V. A Discussion of the Possible Differences Between Demyelination by Organophosphates and Other Secondary Degenerations .................. 471

A. Introduction ....................... 471

B. Lipid Metabolism ....................... 472

C. Protein Míetabolism ................... 474

VI. A Brief Discussion of the Mechanisms of Action of the Neurotoxic Demyelinating Organophosphorus Compounds............................... 474

VII. References......................... 475

\section{Chapter 20}

The Alteration of Brain Metabolism by Narcotic Analgesic Drugs... by Doris $\mathrm{H}$. Clouet

I. Introduction

II. Metabolic Disposition of Narcotic Drugs in Nervous Tissue

A. Uptake and Transport of Narcotic Drugs in the Nervous System

B. Metabolic Conversions of Narcotic Drugs ......

III. Effects of Narcotic Drugs on General Metabolic Systems 
B. Protein Metabolism $\ldots \ldots \ldots \ldots \ldots \ldots \ldots \ldots .485$

C. Nucleic Acid Metabolism ............... 486

D. Lipid Metabolism .................... 487

IV. Effects of Narcotic Drugs on Specific Metabolic Mechanisms .......................... 488

A. Amines .......................... 488

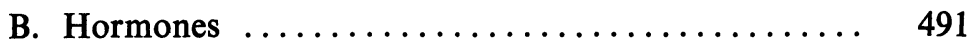

C. Inorganic Ions $\ldots \ldots \ldots \ldots \ldots \ldots \ldots \ldots \ldots, 492$

D. Electropharmacological Responses............ 493

V. Transfer of Tolerance $\ldots \ldots \ldots \ldots \ldots \ldots \ldots \ldots \ldots, 493$

A. Brain Factors ..................... 493

B. Serum Factors $\ldots \ldots \ldots \ldots \ldots \ldots \ldots \ldots \ldots, 494$

VI. Sites of Biochemical Action . . . . . . . . . . . . . . . 494

A. Central Nervous System . . . . . . . . . . . . . . . . . . 494

B. Peripheral Tissue ..................... 496

C. Sites in Single Cells ................... 496

VII. Conclusions........................... 497

VIII. References............................. 498

Chapter 21

Alcohol ........................................ 509

by Henrik Wallgren
I. Introduction $\ldots \ldots \ldots \ldots \ldots \ldots \ldots \ldots \ldots \ldots \ldots \ldots$

II. Respiratory Metabolism .................. 510

A. Observations in Vivo $\ldots \ldots \ldots \ldots \ldots \ldots \ldots, 510$

B. Studies in Vitro ...................... 511

III. Transmitters and Related Compounds $\ldots \ldots \ldots \ldots \ldots \quad 512$

A. Acetylcholine $\ldots \ldots \ldots \ldots \ldots \ldots \ldots \ldots \ldots, 512$

B. Biogenic Amines ................... 513

C. Metabolism and Transport of Amino Acids...... 513

IV. Active Ion Transport .................. 514

V. The Possible Role of Metabolism of Ethanol ....... 515

VI. Effects of Chronic Alcohol Consumption $\ldots \ldots \ldots \ldots .516$

VII. Discussion.............................. 517

VIII. Summary............................ 518

X. References......................... 519

Chapter 22

Effects of Ionizing Radiation $\ldots \ldots \ldots \ldots \ldots \ldots \ldots \ldots \ldots \ldots$

by Enrique Egaña

I. Introduction 
II. Radiation Action on Living Matter with Special Reference to CNS

A. Radiation Action $\ldots \ldots \ldots \ldots \ldots \ldots \ldots \ldots \ldots .526$

B. General Criterion for the Study of CNS Irradiation

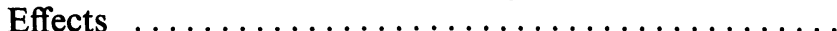

C. The CNS, a Radiobiological Sensitive System ..... 531

III. Neurobiochemical Studies $\ldots \ldots \ldots \ldots \ldots \ldots \ldots \ldots .533$

A. The Respiratory Process and the Oxidative Phosphorylation

B. Carbohydrate Metabolism

533

C. Protein and Amino Acid Metabolism ......... 542

D. Lipid Metabolism $\ldots \ldots \ldots \ldots \ldots \ldots \ldots \ldots \ldots, \quad 545$

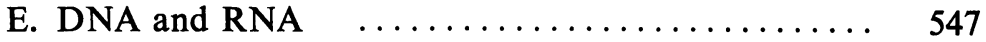

F. Water and Ions ..................... 549

G. Hydrogen Peroxide and Catalase Studies ....... 550

IV. CNS Neurotransmitters $\ldots \ldots \ldots \ldots \ldots \ldots \ldots \ldots \ldots . \ldots 51$

A. Acetylcholine ...................... 551

B. Catecholamines ( $l$-Noradrenaline and Adrenaline) ... 555

C. $\gamma$-Aminobutyric Acid $\ldots \ldots \ldots \ldots \ldots \ldots \ldots, \ldots 55$

D. 5-Hydroxytryptamine $\ldots \ldots \ldots \ldots \ldots \ldots \ldots \ldots, 556$

V. Concluding Remarks................... 558

VI. References $\ldots \ldots \ldots \ldots \ldots \ldots \ldots \ldots \ldots \ldots \ldots \ldots, \quad 560$

Subject Index......................... 575 